\title{
Individual moods and Auditor's Professional Skepticism
}

\author{
Koroush Amani \\ Ph.D Student of Accounting , Department of Accounting, Islamic Azad University, \\ Tehran Science and Research Branch, Tehran \\ kouroshamani@yahoo.com \\ Hashem Nikoumaram* \\ Professor of Accounting , Department of Accounting, Islamic Azad University, \\ Tehran Science and Research Branch,Tehran(Corresponding author) \\ h-nikoumaram@srbiau.ac.ir \\ Bahman Banimahd \\ Associate Professor of Accounting, Department of Accounting, Islamic Azad \\ University, Karaj Branch, Karaj \\ dr.banimahd@gmail.com
}

\begin{abstract}
:
Professional skepticism is a basic concept in audit decision-making and judgment and a lack of it may decrease audit quality. Recently, the subject of professional skepticism has been noticed by the audit scholars. Recent empirical studies have showed that auditor's judgment and decision making would rise from behavioral and recognition subjects. Hence, the aim of this paper is to study the effect of positive and negative moods on auditor's professional skepticism as an element of the auditor's judgment and decision making. This research is functional from study objective point of view and is a survey from methodology point of view. The theoretical framework and literature review is collected through archival approach. Data collection is based on questionnaire. The statistical sample are 107 auditors who are working in audit firms and time of research conduct is 2017. We use multiple regression to analysis of the research data.

The result of this study show that, there is a positive and significant relationship between the positive mood and professional skepticism. Also the relationship between negative mood and professional is negative and significant.
\end{abstract}

Keywords: Professional Skepticism, Judgment and Decision Making and Positive and Negative Mood.

\section{Copyrights}

This license only allowing others to download your works and share them with others as long as they credit you, but they can't change them in any way or use them commercial. 


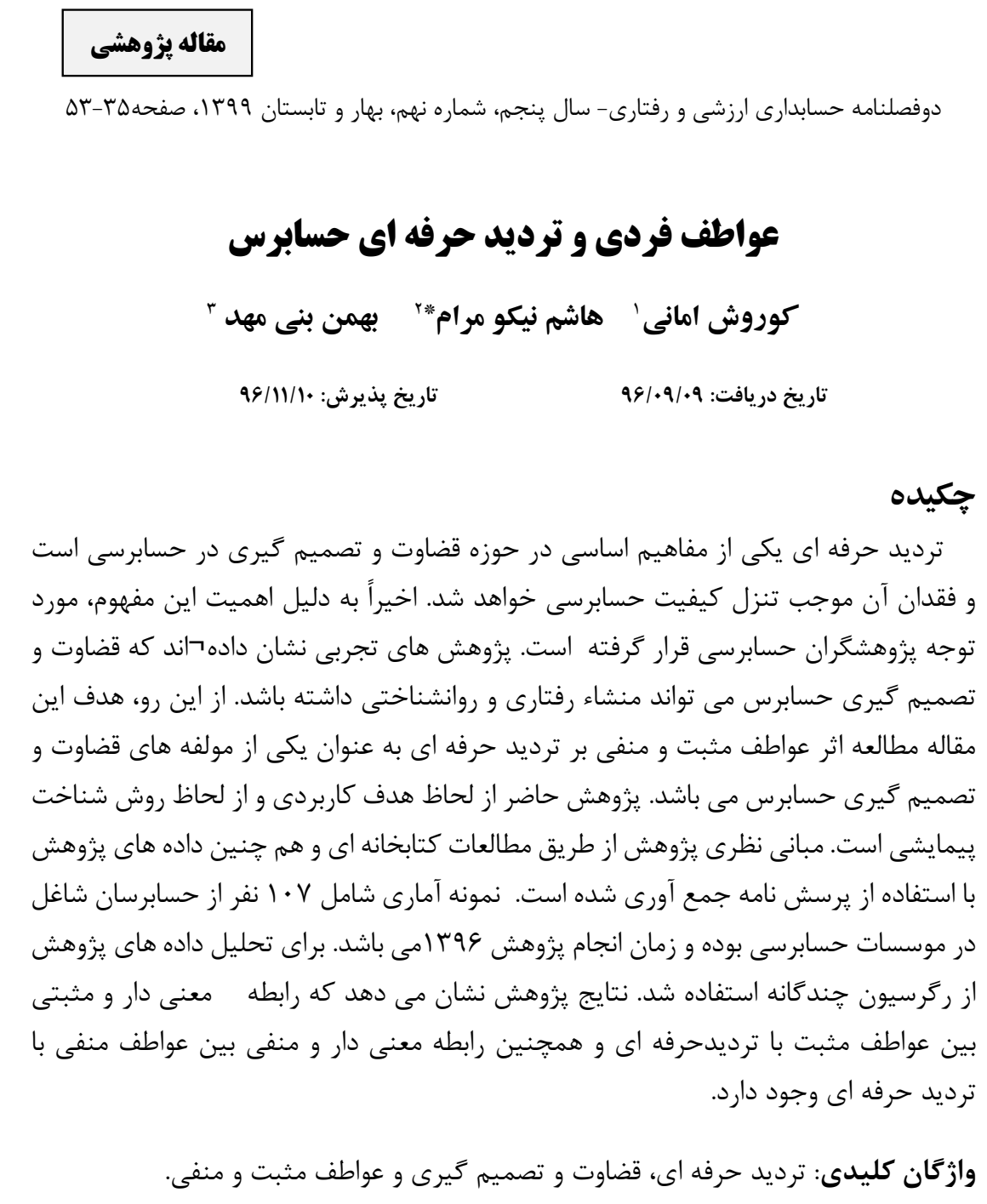

\footnotetext{
'انشجوى دكترى حسابدارى دانشعاه آزاد اسلامى واحد علوم و تحقيقات kouroshamani@yahoo.com

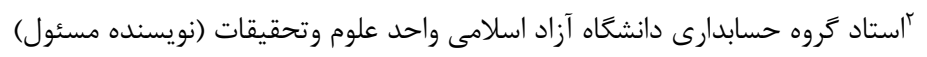
h-nikoumaram@srbiau.ac.ir dr.banimahd@gmail.com دانشيار كروه حسابدارى دانشعاه آزاد اسلامى واحد كرج
} 


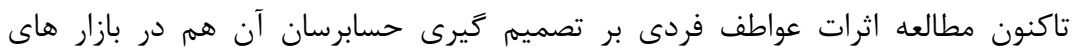

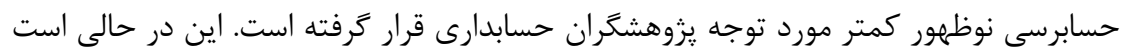

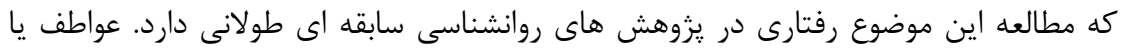

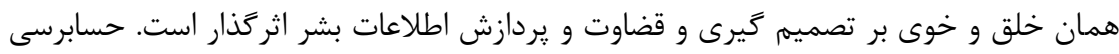

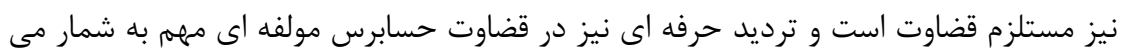
آيد. عواطف فردى به دو صورت مى تواند بر تصميم كيرى و قضاوت افراد تاثير داشته باشد.

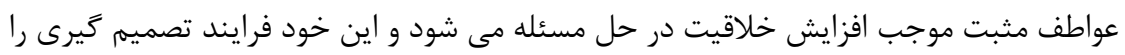

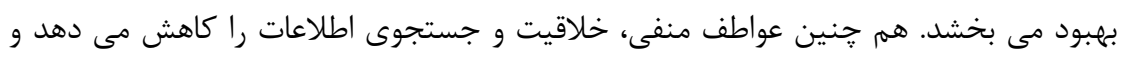

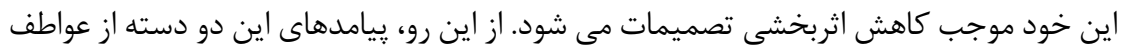

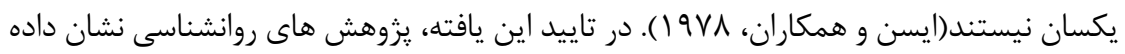

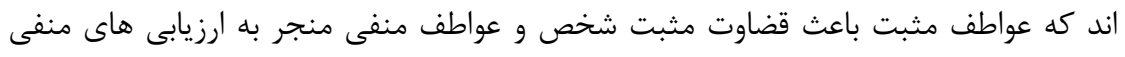

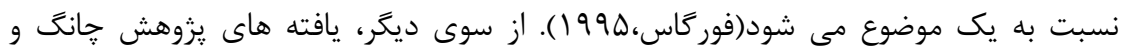

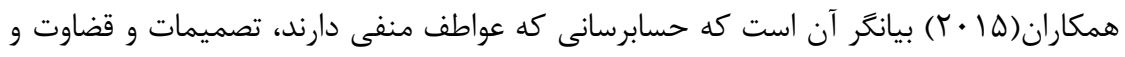

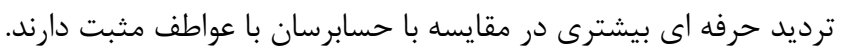

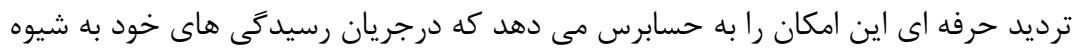

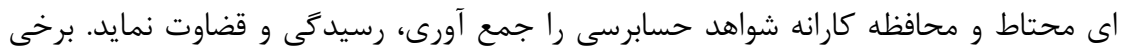

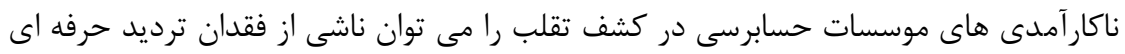

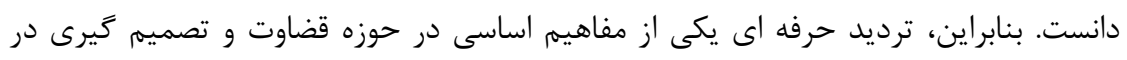

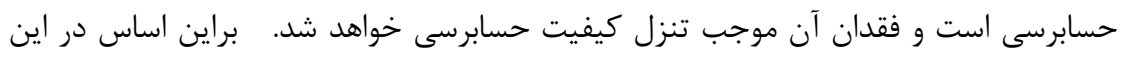

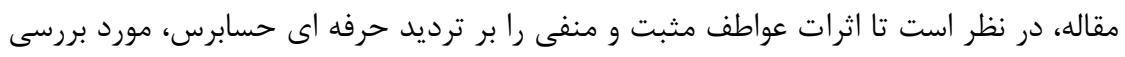

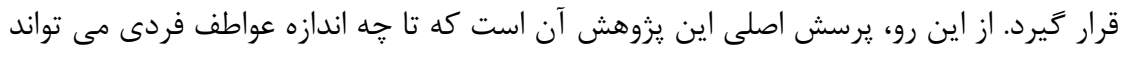

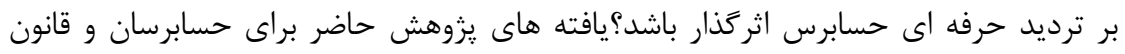

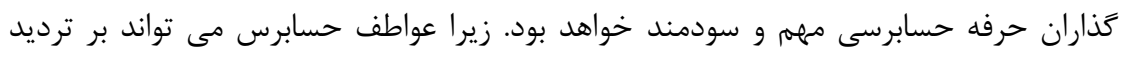

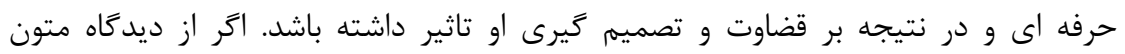

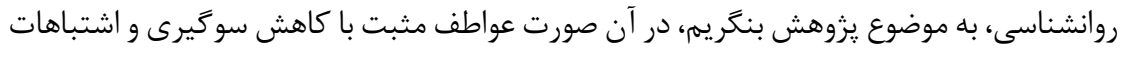

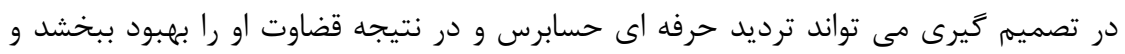

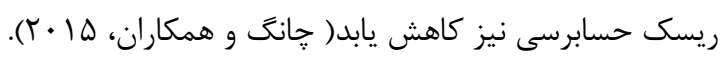

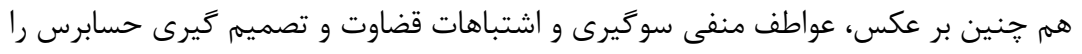

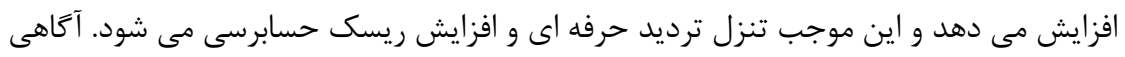




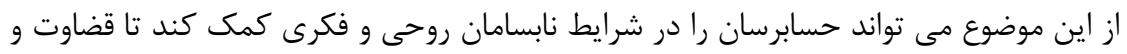

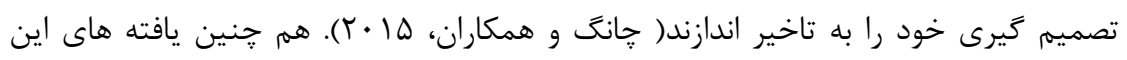

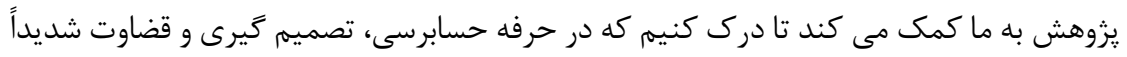

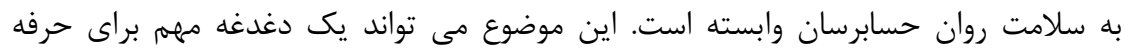

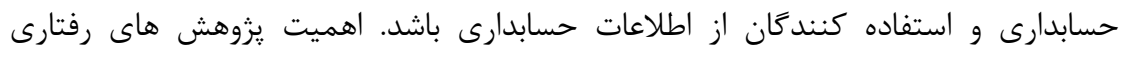

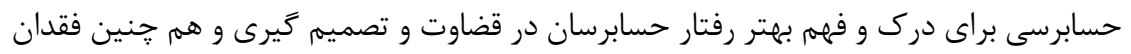

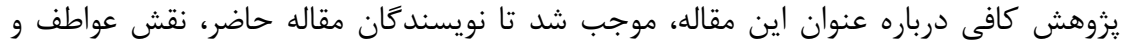

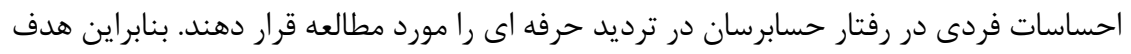

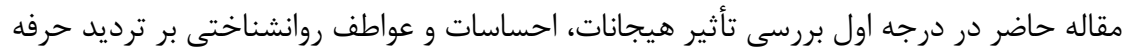
اى حسابرس است. هدف دوم اين يزوهش نيز بسط و گسترش مبانى نظرى يزوهش هایى داى رفتارى

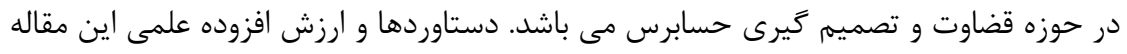
رامى توان به شرح زير برشمرد:

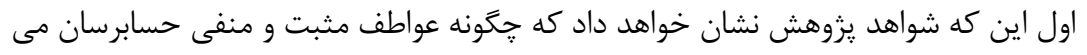

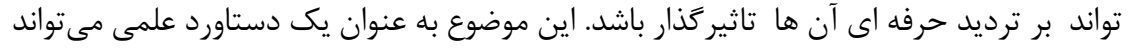

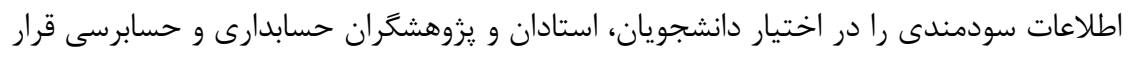

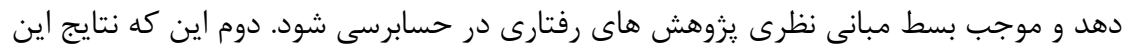

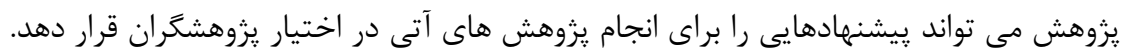

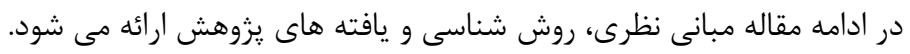

\section{r-مبانى نظرى و يِيشينه يزوهش

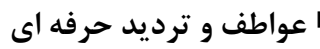

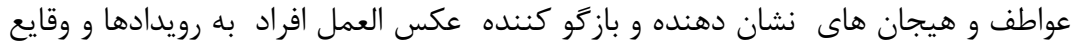

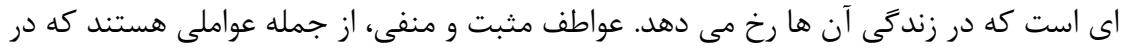

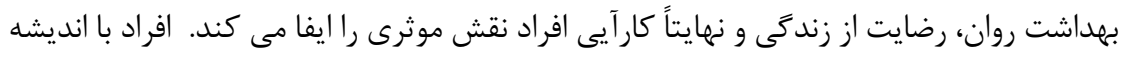

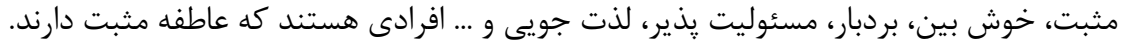

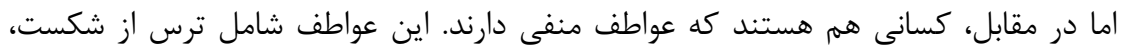

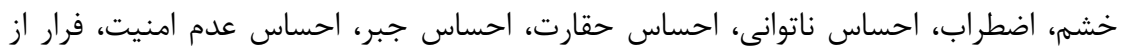

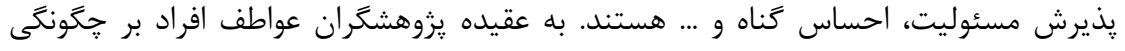

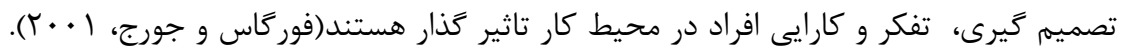

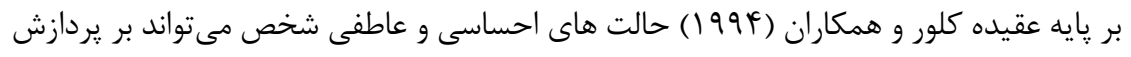


اطلاعات، از انتخاب اطلاعات كرفته تا رمزكذارى اطلاعات و بازيابى آتى آن از حافظه، اثر

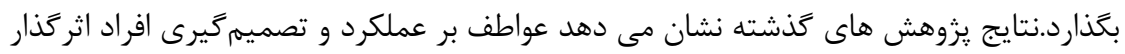
است. به اين شكل كه احساسات و عواطف خوب موجب ايجاد نحاهى مثبت به موضوع و وضعيت دمان

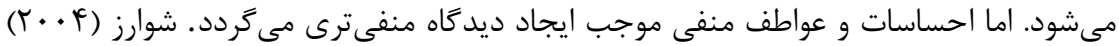

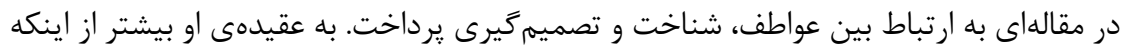

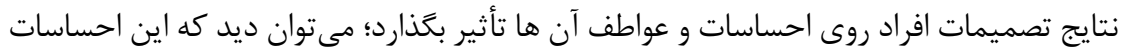

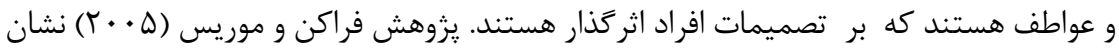

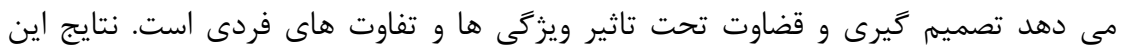

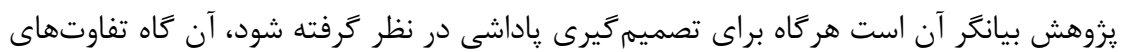

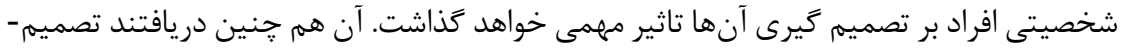

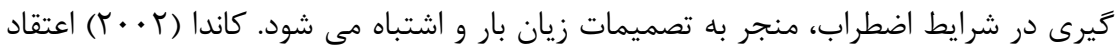

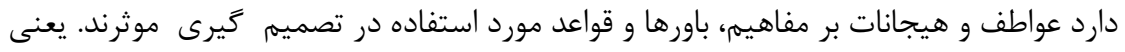
افراد از قواعدى در تصميم كيرى و قضاوت استفاده مى كنند كه با اهداف و عواطف آن ها هماهنَ

بعلاوه هيجانات و عواطف نحوه يردازش اطلاعات را نيز تعيين مى كنند. به اين صورت كه

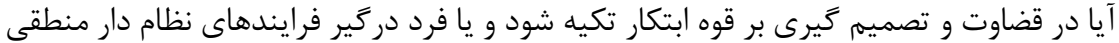

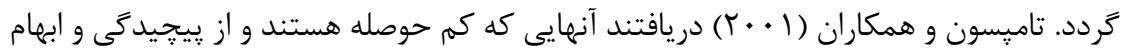

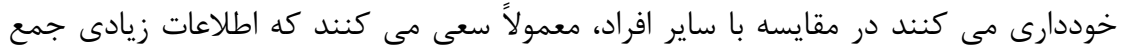
آورى نكنند و به دنبال حذف سريع ترديدها و رسيدن به معنا و مقصود هستند.

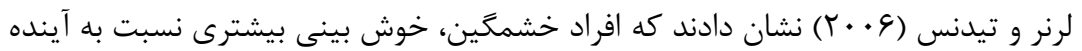

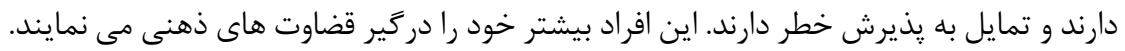

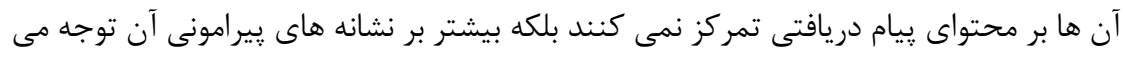

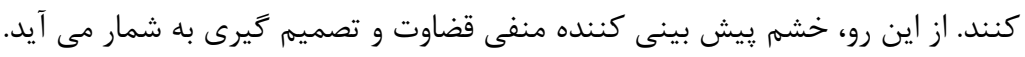

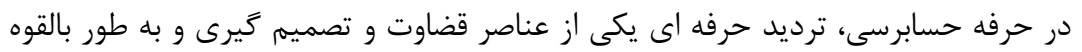

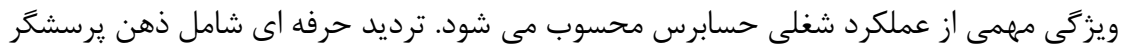

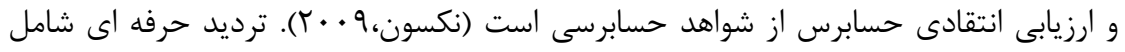

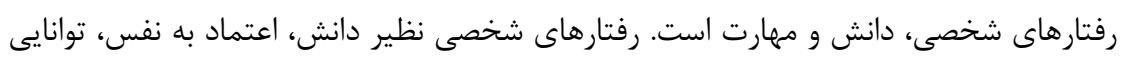

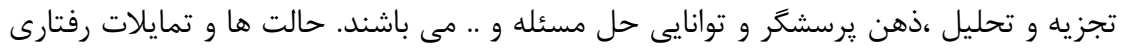

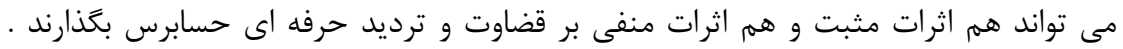

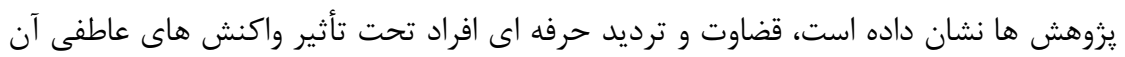


ها است. اين يافته ها تأكيد دارند كه تصميم كيرى و قضاوت افراد مستلزم موازنه ميان عواطف

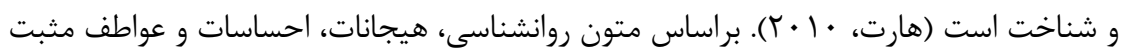

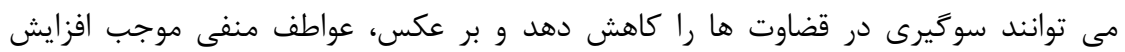

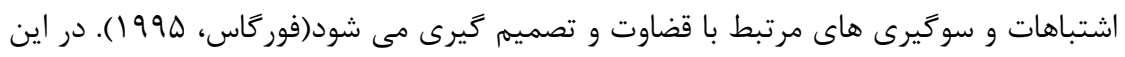

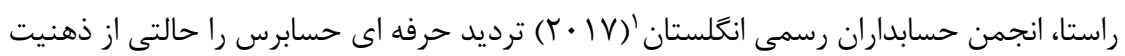

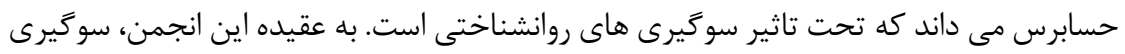

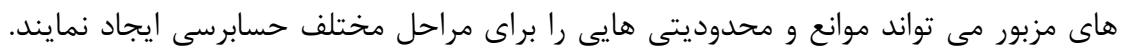

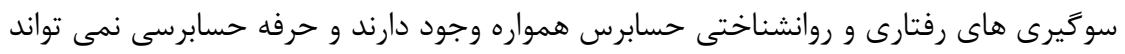

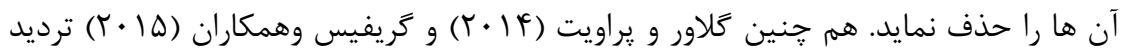

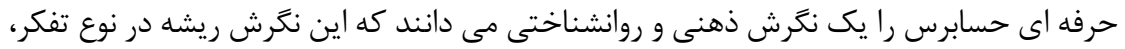

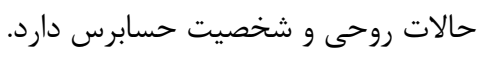

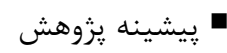

يزوهشكران در مطالعه اى رابطه ميان ترديد حرفه اى حسابرس را با سطح اعتماد حسابرس برس

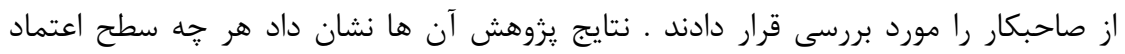

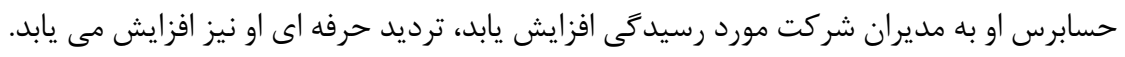

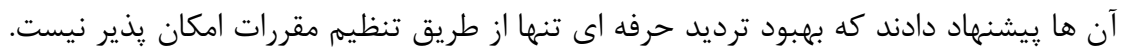

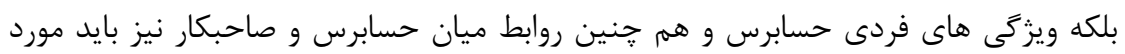

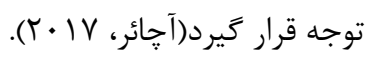

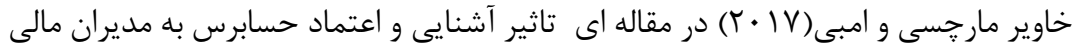

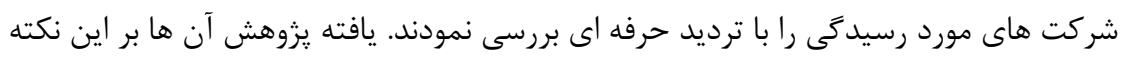

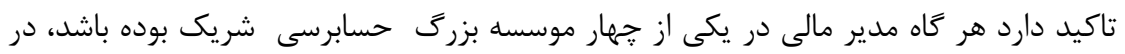

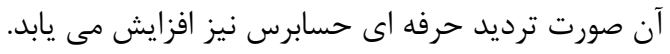

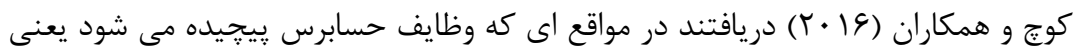

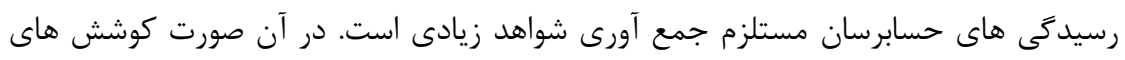

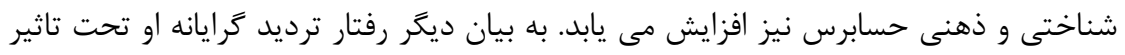

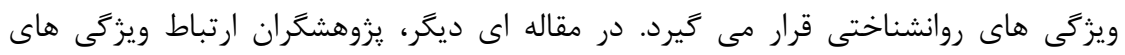

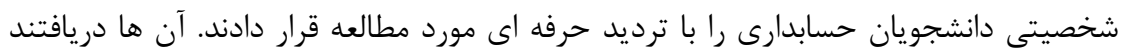

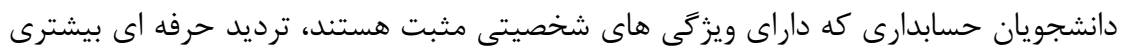

1 - ACCA 
در مقايسه با ساير دانشجويان دارندهم جنين اين دانشجويان درك بهترى از ارائه اطلاعات صورت

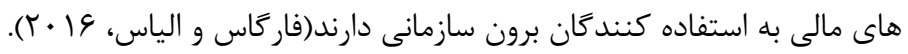

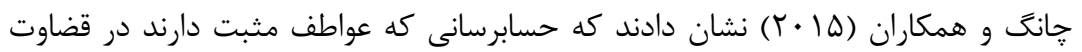
هاى مربوط به ارزشيابى موجودى كالا، در مقايسه با حسابرسان با عواطف منفى، قضاوت محافظه

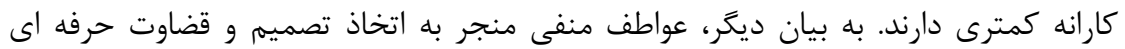
محافظه كارانه توسط حسابرس مى شود.

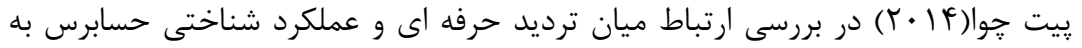

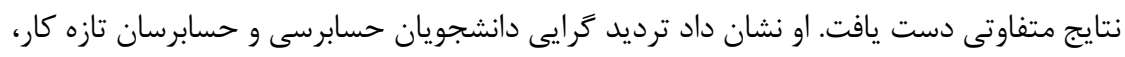

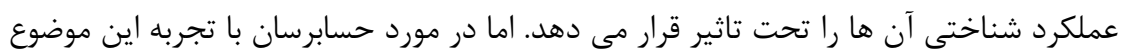

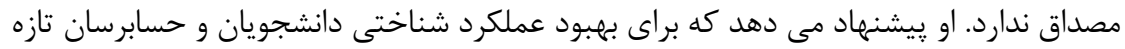

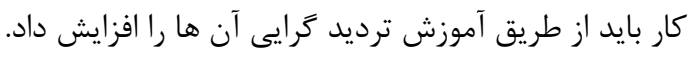

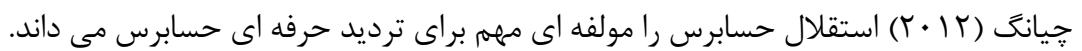
او عقيده دارد كه به دليل سوكيرى هاى شناختى و روابط حاكم ميان صاحبكار و حسابرس ممكن

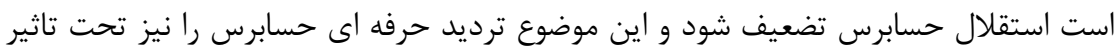

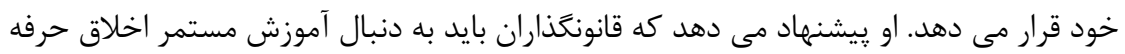
اى براى حسابرسان باشند تا استقلال حسابرس و در نتيجه ترديد حرفه ایى او تضعيف نشوداد

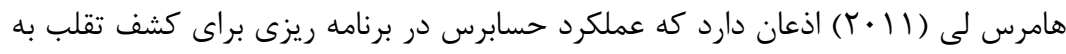

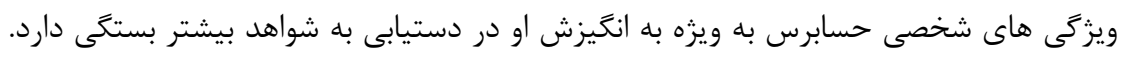

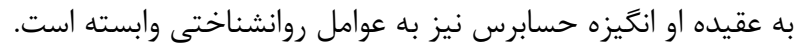

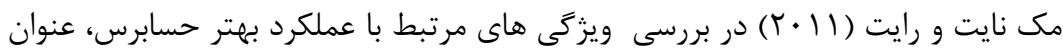

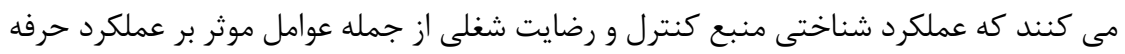

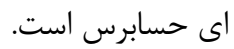

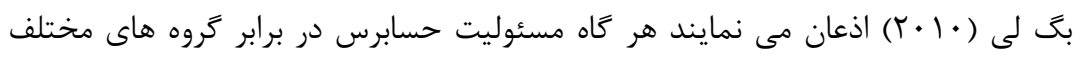

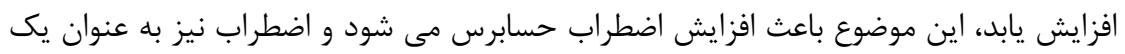

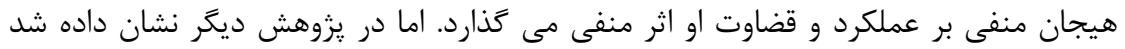

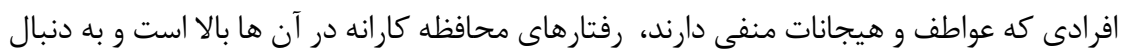

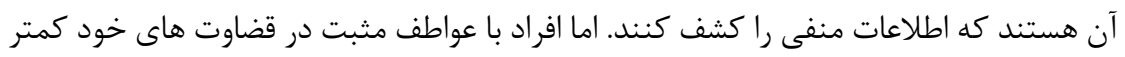

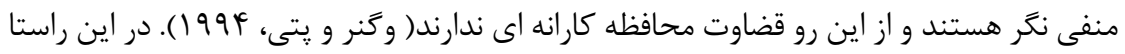

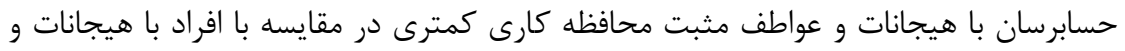

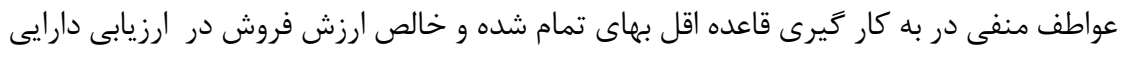


ها دارند . يافته هاى يزوهشكَران نشان مى دهد عواطف منفى موجب مى شود تا حسابرس در

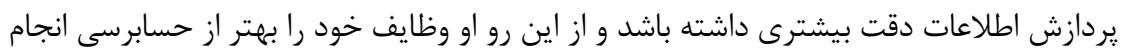

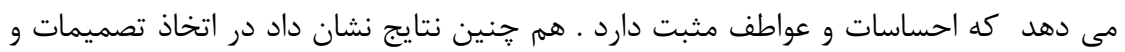

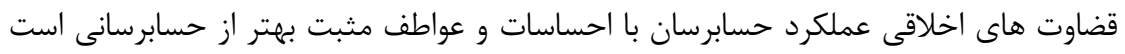
كه عواطف منفى دارند(سيانسى و بير استيكر، 9 . • (T).

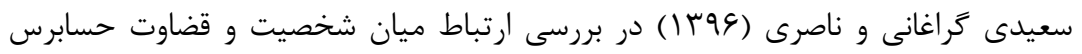

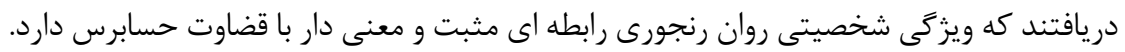

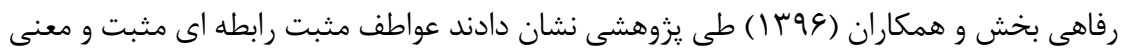

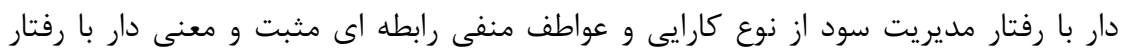
مديريت سود از نوع فرصت طلبانه دارد.

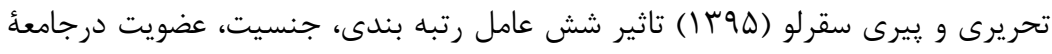

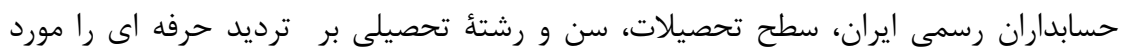

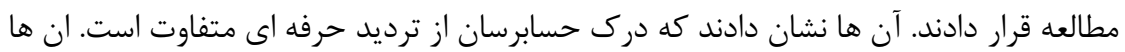

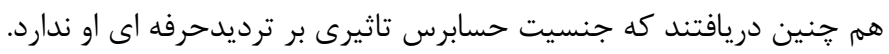

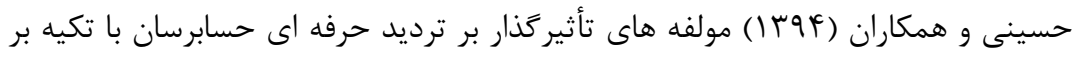

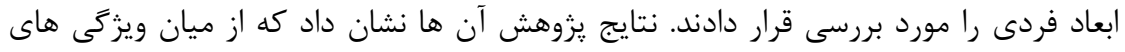

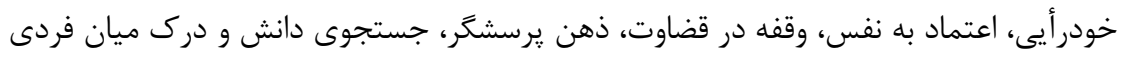

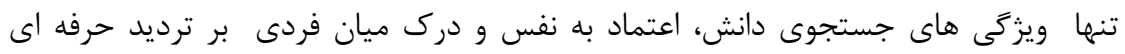

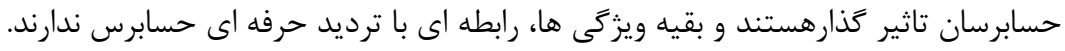

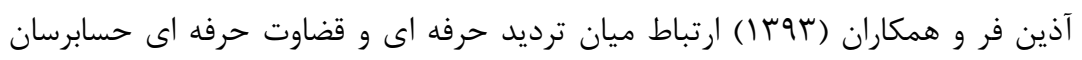

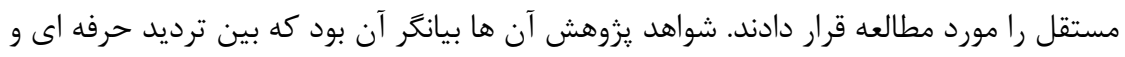
قضاوت حرفه اي رابطه معنادار و مثبتى وجود دارد.

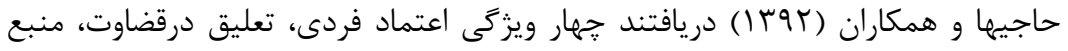

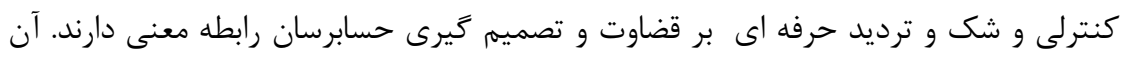

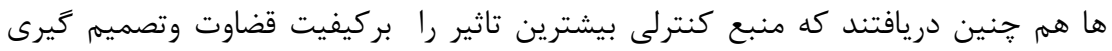

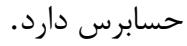

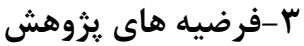

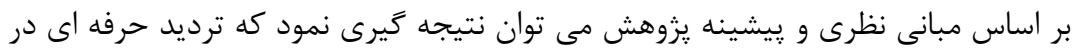

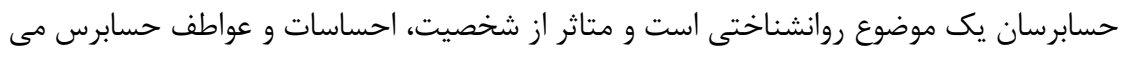


باشد. همانطور كه بيان شد مطابق نظر קانغ و همكاران(ها •(Y)، عواطف مثبت با كاهش سو

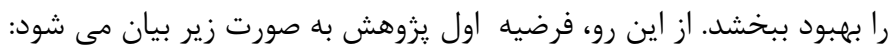
فرضيه اول: عواطف مثبت با ترديدحرفه اى حسابرس رابطه مثبت دارد.

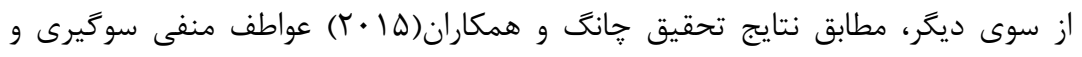
اشتباهات قضاوت و تصميم كيرى حسابرس را افزايش مى دهد دابع و اين موجب تنزل ترديد حرفه

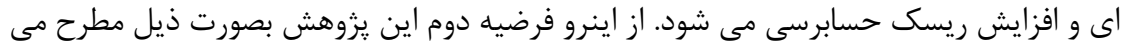

فرضيه دوم: عواطف منفى با ترديدحرفه اى حسابرس رابطه منفى دارد.

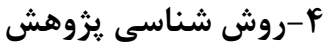

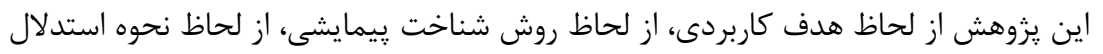

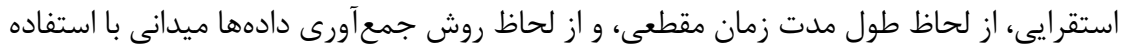

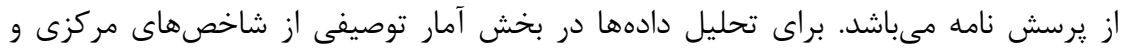

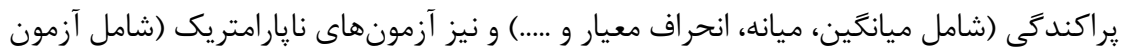

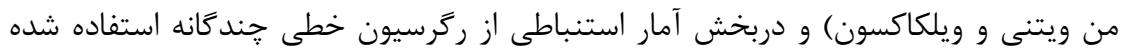

متغير وابسته در اين يزوهش، ترديدحرفه اى و متغير هاى مستقل يزوهش نيز عواطف مثبت

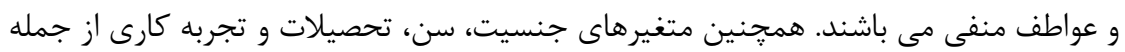

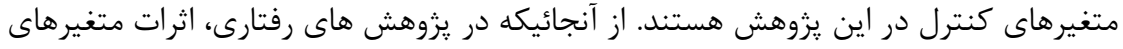

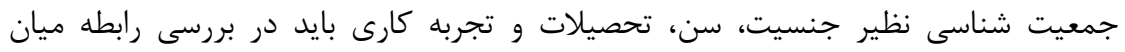

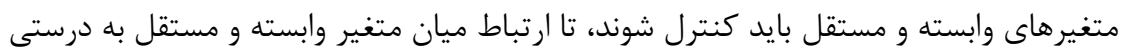

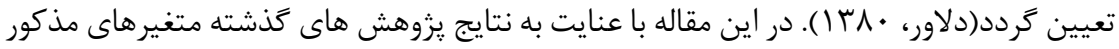

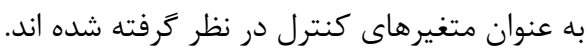

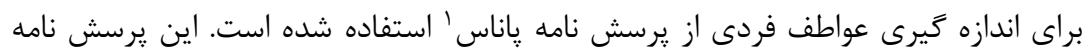

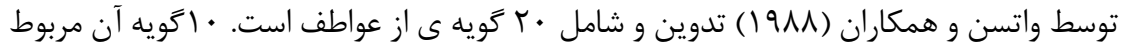

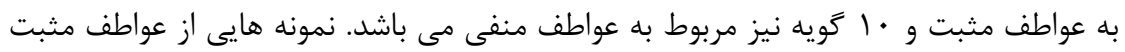

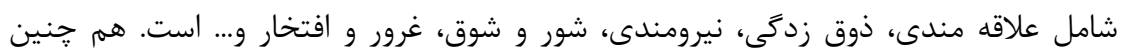

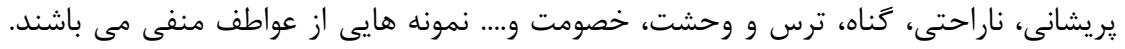

${ }^{1}$ The Positive and Negative Affect Schedule(PANAS) 
كويه ها روى مقياس بنج درجه اى ليكرت (

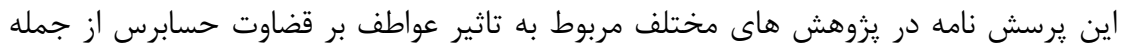

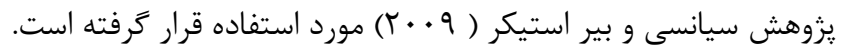

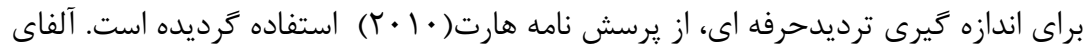

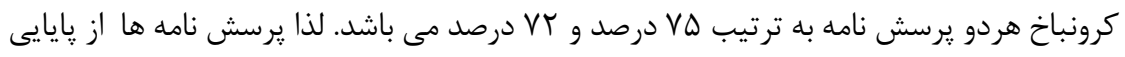
كافى برخوردار هستند. جامعه آمارى در اين يزوهش، حسابرسان شاغل در موسسات حسابرسى عضو جامعه حسابداران

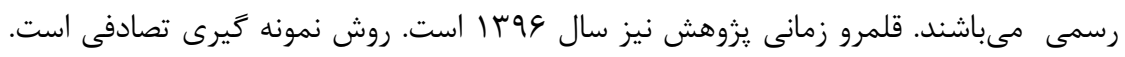

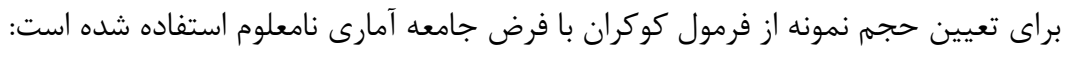
$n=\frac{Z_{\frac{\alpha}{2}}^{2} p q}{d^{2}}$

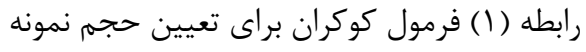
در اين فرمول:

تعداد نمونه=

مقدار نرمال استاندارد يعنى

$\mathrm{P}=\mathrm{q}=\cdot \mathrm{.}$

$d=.1$

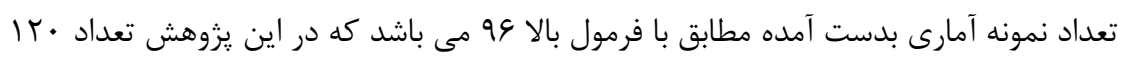

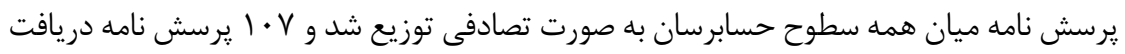

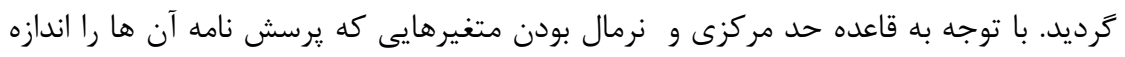

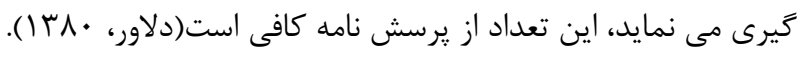

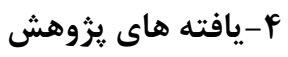

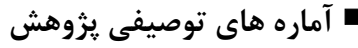

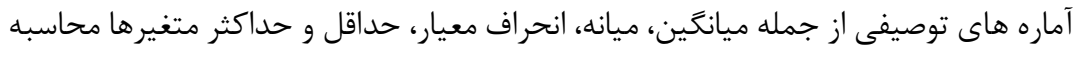

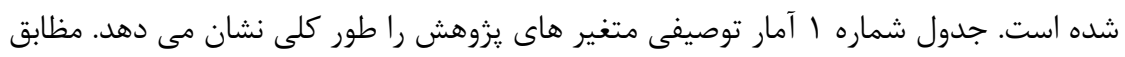

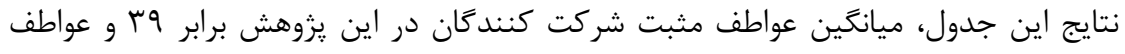

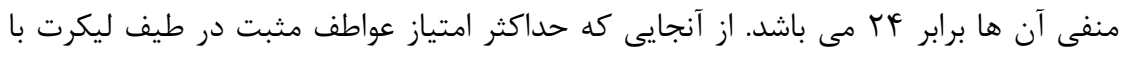

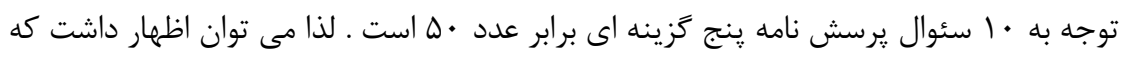

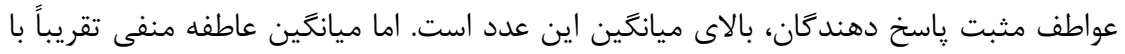

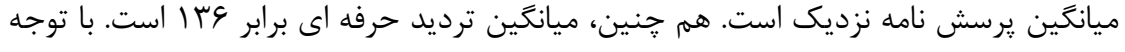


به اين كه حداكثر امتياز ترديد حرفه اى در طيف ليكرت با توجه به ·r سئوال يرسش نامه شش

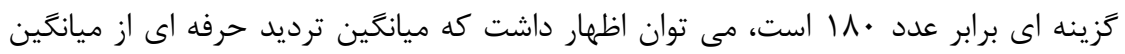

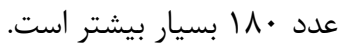

\begin{tabular}{|c|c|c|c|c|}
\hline \multicolumn{5}{|c|}{ جدول 1 - آمار توصيفى } \\
\hline ترديد حرفه اى & عواطف منفى & عواطف مثبت & تجربه كارى - سال & شرح \\
\hline $\mid r G / 4$. & Tr/GQ & |N/Tl & $9 / 9$ & ميانگين \\
\hline Irk & TF & rq & $\wedge$ & ميانه \\
\hline $19 / 1 \mathrm{~V}$ & $V / .9$ & g/VF & $V / \cdot r$ & انحراف معيار \\
\hline V. & $1 \cdot$ & 10 & 1 & حداقل \\
\hline IVV & is & $\Delta$. & rq & حداكثر \\
\hline
\end{tabular}

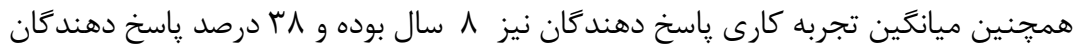

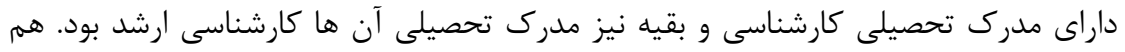

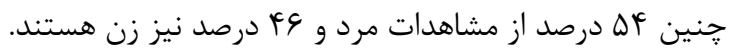

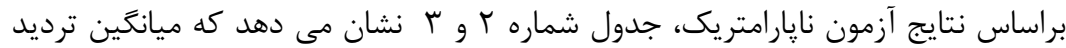
حرفه ایى در حسابرسان با عواطف مثبت و منفى تفاوت معنى دارى با هم ندارند. زيرا سطح معنى داريا

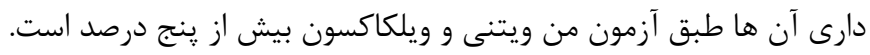
جدول r- آزمون مقايسه ميانگين

\begin{tabular}{|c|c|c|c|}
\hline مجموع رتبه ها & ميانگين رتبه & جنسيت & شرح \\
\hline$r q \Delta \Delta / \Delta$ & 0.199 & زن - ان & \multirow{2}{*}{ ترديد حرفه اي } \\
\hline TATY/D & $\Delta V / G$ & مرد & \\
\hline rito/d & QH/QT & زن & \multirow{2}{*}{ عواطف مثبت } \\
\hline$r \& \Delta \cdot 10$ & $\Delta F / \cdot q$ & مرد & \\
\hline rThl & $\Delta \varphi / \Delta V$ & زن & \multirow[t]{2}{*}{ عواطف منفى } \\
\hline rFqV & 0.199 & مرد & \\
\hline
\end{tabular}

جدول r- ادامه آزمون مقايسه ميانگين

\begin{tabular}{|c|c|c|c|}
\hline عواطف منفى & عواطف مثبت & ترديد حرفه اى & شرح \\
\hline ITVK & ITFY/D & ITFY/D & آماره من ويتنى \\
\hline TYqV & TITV/D & $r q \Delta \Delta / \Delta$ & آماره ويلكاكسن \\
\hline - & $-\cdot / \cdot r \Lambda$ & $-1 / 1 \cdot 4$ & آماره Z \\
\hline$\cdot|r \Delta|$ & $.19 \vee \wedge$ &.$/ T V$. & سطح معنى دارى \\
\hline
\end{tabular}




\section{n همبستكَى ميان متغيرهاى يزوهش}

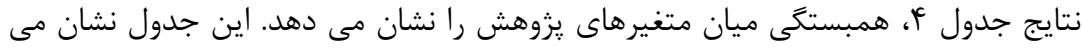

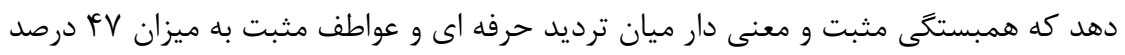
وجود دارد. اما رابطه ميان ترديد حرفه ايى و عواطف منفى به ميزان آب درصد منفى و معنى دار مى باشد.

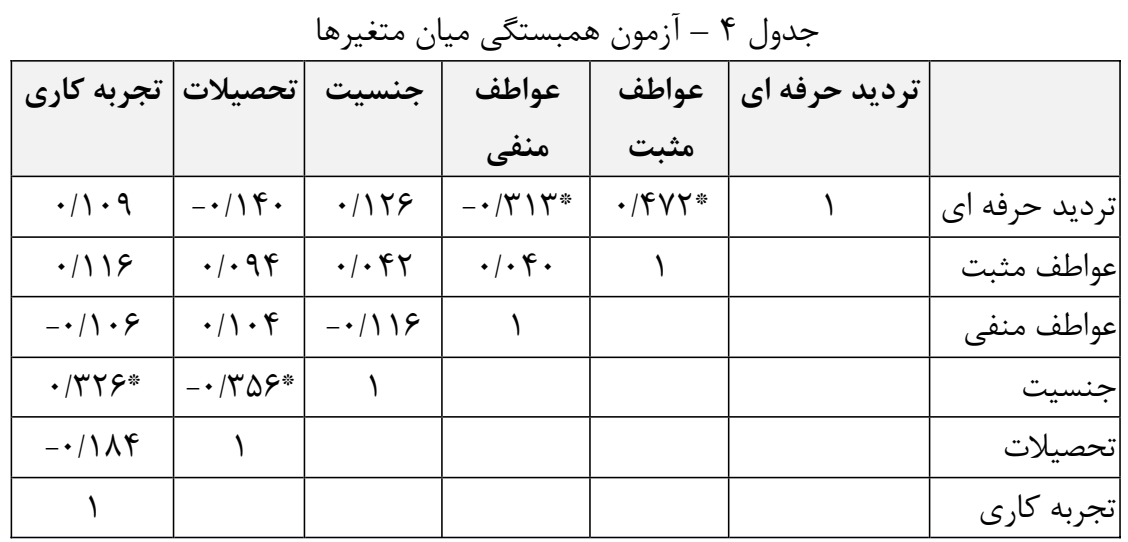

*در سطح اطمينان DQ درصد همبستخى معنى دار مى باشد

\section{سآزمون فرضيه هاى يثوهش}

قبل از آزمون فرضيه ها، مفروضات ركرسيون مورد بررسى قرار ترفته است. مهمم ترين آن ها

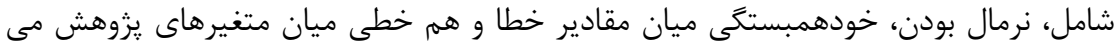

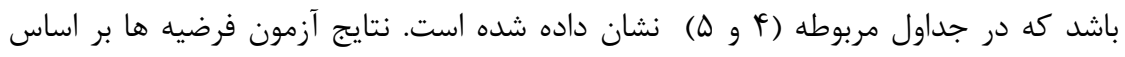
ركرسيون קند متغيره در جدول شماره ه ارائه شده است. طبق شواهد اين جدول از آندان آنجاييكه سطح معنى دارى متغير عواطف مثبت كمتر از ها درصد يعنى صفر است، بنابراين با اطمينان

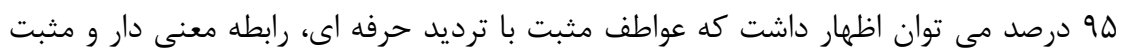

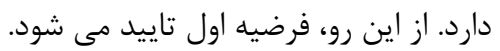

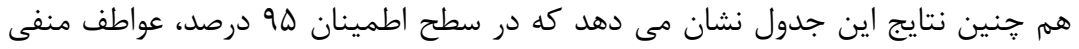

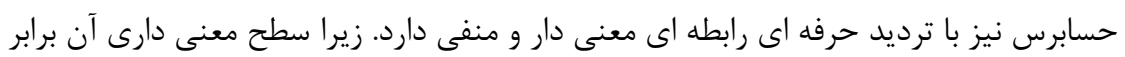

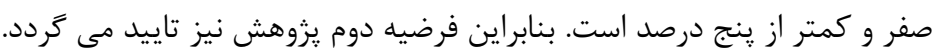

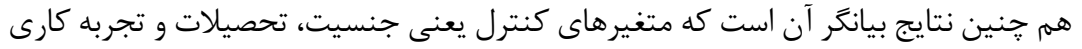

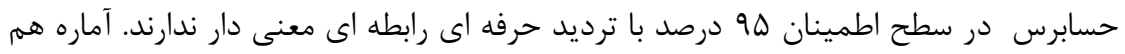

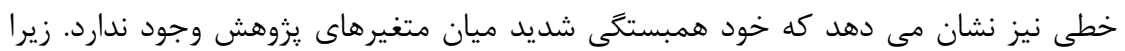




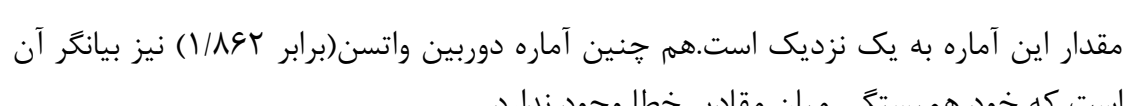

است كه خود همبستكى ميان مقادير خطا وجود ندارد.

جدول ه - آزمون فرضيه ها ماندان

\begin{tabular}{|c|c|c|c|c|}
\hline آماره هم خطى & سطح معنى دارى & 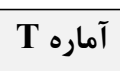 & 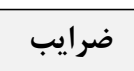 & شرح \\
\hline- &.$\cdots$ & $|Y / \cdot V|$ & $11 \% / 9 T \pi$ & مقدار ثابت \\
\hline $1 / \cdot \Delta \Delta$ & $.1 \cdots$ & $\Delta / T \wedge T$ & $1 / / \Delta 1$ & عواطف مثبت \\
\hline $1 / \Delta r$ & $.1 \cdot$ & $-r / \wedge \vee 1$ & $-\cdot / \Lambda r V$ & عواطف منفى \\
\hline $1 / 19$. & ./Vq4 & . /TET & . INDT & جنسيت \\
\hline $1 / 149$ & $\cdot / \pi \cdot \Lambda$ & $-1 / 4 V I$ & $-4 / .91$ & تحصيلات \\
\hline \multirow[t]{2}{*}{$1 / 1 \Delta V$} & $\cdot / \Lambda \Delta \Lambda$ & -.1189 & $-\cdot|\cdot 4|$ & تجربه كارى \\
\hline & $.1 \cdot$ & & D/r D & 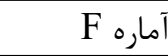 \\
\hline \multicolumn{2}{|c|}{ دوربين واتسن = 1/КFT } & \multicolumn{3}{|c|}{ ضريب تعيين تعديل شده = \&/•r درصد } \\
\hline
\end{tabular}

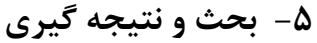

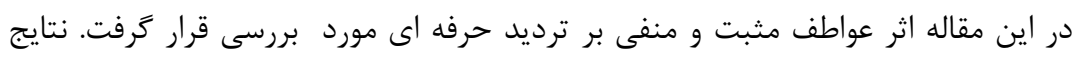

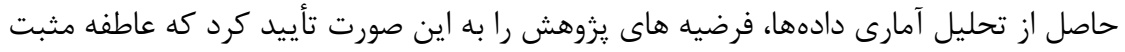

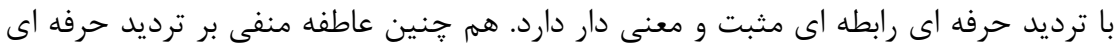

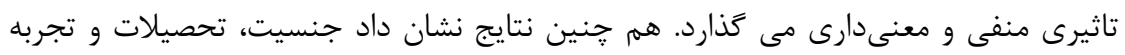

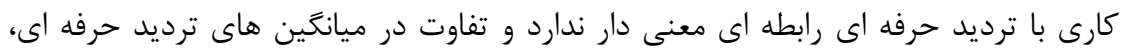

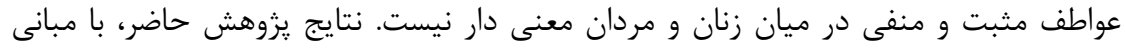

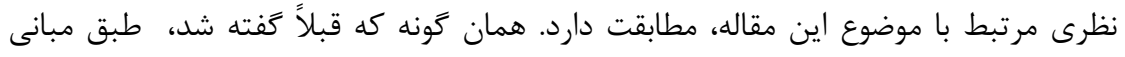

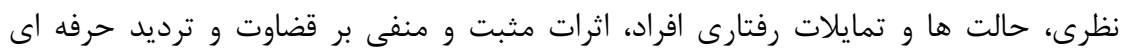

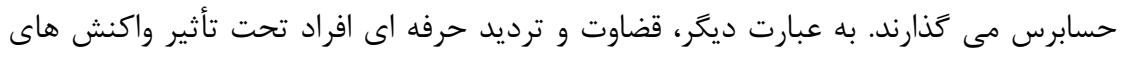

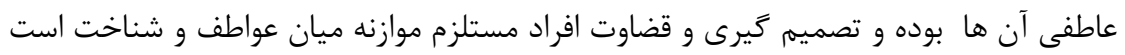

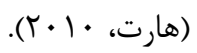

براساس متون روانشناسى مثبت كرا، هيجانات، احساسات و عواطف مثبت مى توانند سو گيرى در قضاوت ها را كاهش دهد و بر عكس، عواطف منفى موجب افزايش اشتباهات و سوكيرى هاى

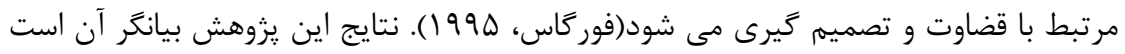

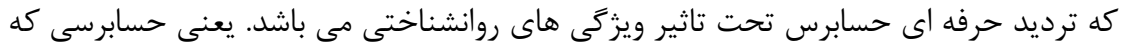

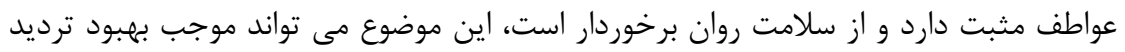

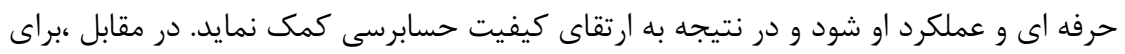


حسابرسانى كه عواطف منفى دارند يعنى كسانى كه از سلامت روان كمترى برخوردار هستند،

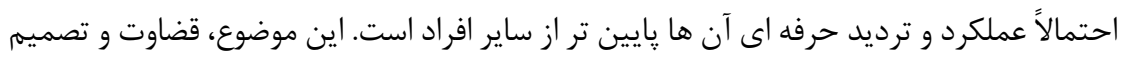

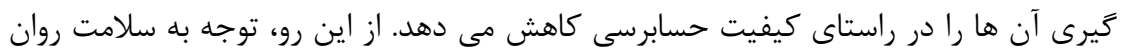

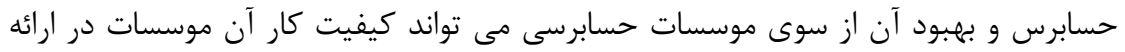

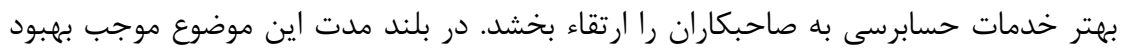

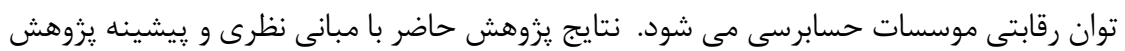

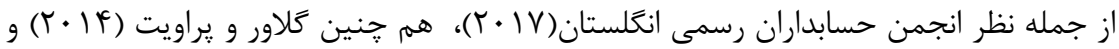

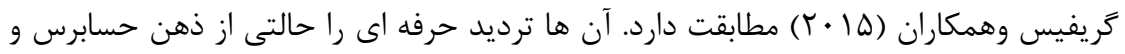

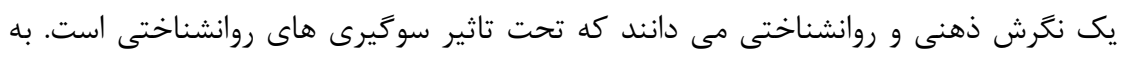

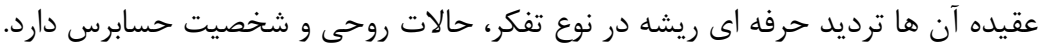

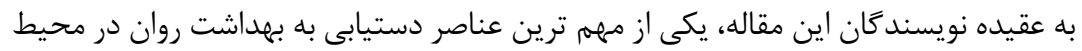

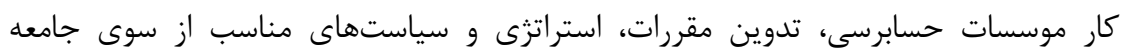

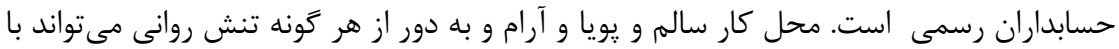

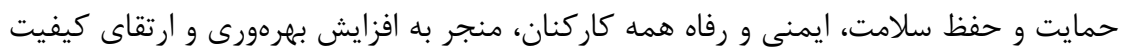

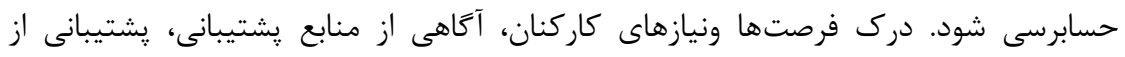

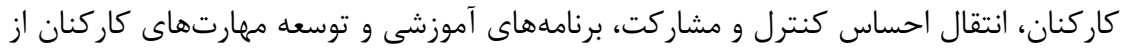
جمله مهمترين عوامل افزايش سلامت روان در محيط كار است. عوامل خطر متعددى برد براى

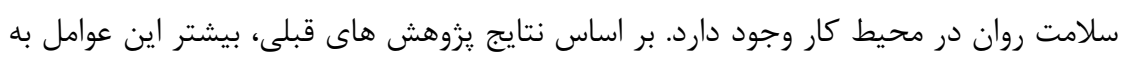

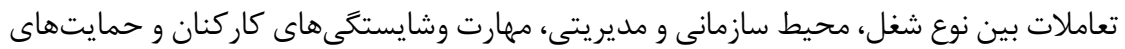

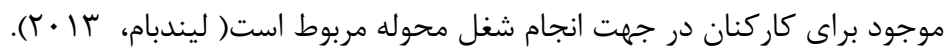

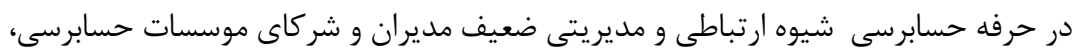
عدم مشاركت حسابرسان در تصميم گيرى ها، عدم حمايت از حسابرس، ساعات كارى غير

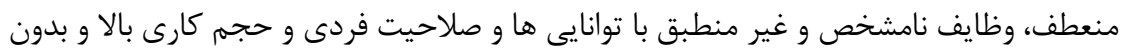

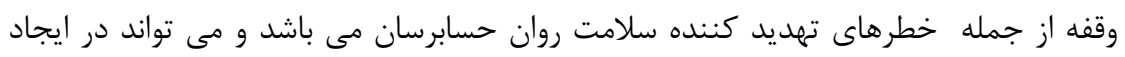
عواطف منفى در حسابرسان موثر باشد. اين خطرها مى تواند ريسك حسابرسى را افزايش دهان دهد

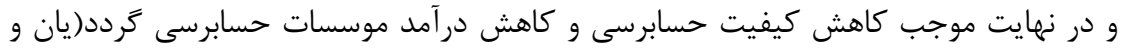

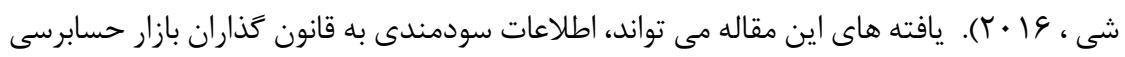

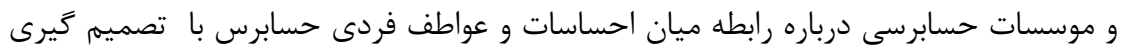

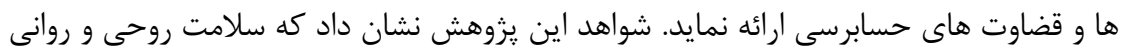
حسابرسان، موضوعى با اهميت براى حرفه حسابرسى است. اهميت ائه اين موضوع در آن آن است كه 
سلامت روان مى تواند ترديدحرفه اى حسابرسان را بهبود بخشد و اين خود موجب ارتقا كيفيت

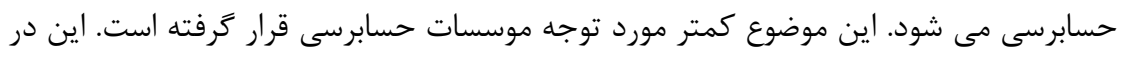

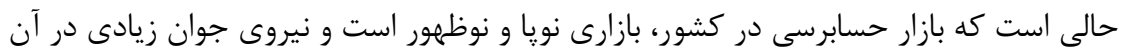

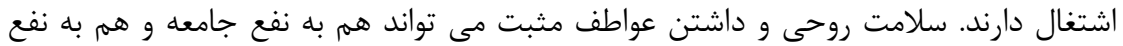

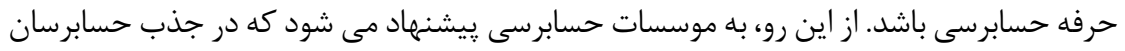

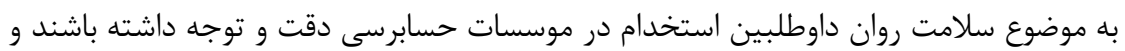

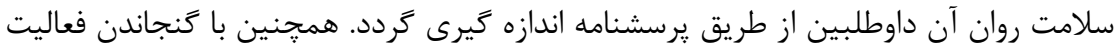

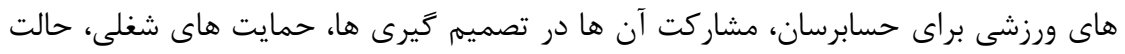

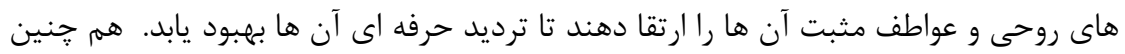
براى يزوهش هاى آتى ييشنهاد مى شود ساير جنبه هاى روانشناختى نظير بيش اعتمادى

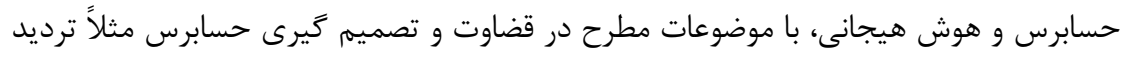
حرفه اى مورد بررسى قرار گيرد.

V- تقدير ، تشكر و ملاحظه هاى اخلاقى ادي

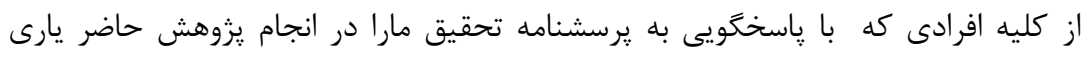

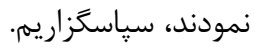

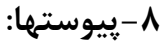 \\ الف: برسش نامه عواطف فردى}

مقياس حاضر شامل برخى وازه ها است كه احساسات و هيجانات متفاوت را توصيف مى كند.

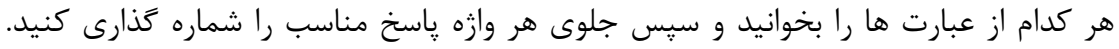

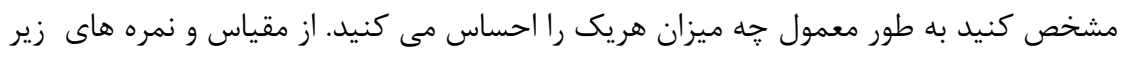

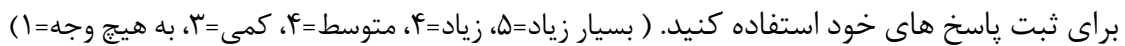

\begin{tabular}{|c|c|c|c|}
\hline نمره & نوع احساسات و هيجانات & نمره & نوع احساسات و هيجانات \\
\hline$\ldots \ldots \cdots \cdots$ & |زود رنجى & $\ldots \ldots \cdots \cdots$ & علاقه مندى \\
\hline$\ldots \ldots \ldots \ldots \ldots$ & هوشيارى و زيركى & $\ldots \ldots \ldots \ldots \ldots$ & إيريشانى \\
\hline$\ldots \ldots \ldots \ldots$ & شرمسارى & $\ldots \ldots \ldots \ldots$ & ذا ذوق زدگى \\
\hline ............. & خوش ذوقى & $\ldots \ldots \ldots \ldots$ & ناراحتى \\
\hline$\ldots \ldots \ldots \ldots$ & |بى قرارى & $\ldots \ldots \ldots \ldots$ & | نيرومندى \\
\hline$\ldots \cdots \cdots \cdots$ & | مصمم & $\ldots \cdots \cdots \cdots \cdots$ & كناه \\
\hline$\ldots \ldots \ldots \ldots . . .$. & |متوجه و دقيق & ................ & ترس و وحشت \\
\hline
\end{tabular}


دكتر نيكومرام و همكاران، عواطف فردى و ترديد حرفه ایى حسابرس

\begin{tabular}{|c|c|c|c|}
\hline ………...... & عصبى & ………....... & خصومت \\
\hline ……............ & فعال & ………........ & شور و شوق \\
\hline …….......... & هراسان & ................... & غرور و افتخار \\
\hline
\end{tabular}

\section{ب: يرسش نامه ترديد حرفه اي}

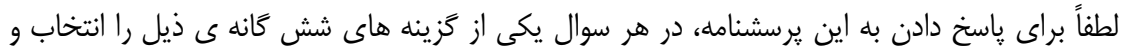

\begin{tabular}{|c|c|c|c|c|c|c|c|}
\hline 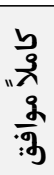 & & & & & 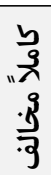 & سئوالات & $\hat{\mathfrak{j}}$ \\
\hline \& & $\Delta$ & f & r & 4 & 1 & من اغلب توضيحات ديخران را بدون اينكه درباره آنها فكر كنم مى يذيرم & 1 \\
\hline 4 & $\Delta$ & i & r & 4 & 1 & |من درباره خودم احساس خوبى دارم . & r \\
\hline 4 & $\Delta$ & f & r & r & 1 & من بيشترى بتوانم تصميم كيرى درباره موضوعات صبر مى كنم تا اطلاعات & r \\
\hline 4 & $\Delta$ & i & $r$ & t & 1 & |انتظار يادگيرى براى من هيجان انگَيز است . & i \\
\hline 4 & $\Delta$ & i & r & $r$ & 1 & من علاقه مندم تا دلايل رفتار افراد در انجام كارها را بدانم. & $\Delta$ \\
\hline 4 & $\Delta$ & f & r & t & 1 & |من به توانايى هاى خود اطمينان دارم . & 4 \\
\hline \& & $\Delta$ & if & r & r & 1 & من تا درستى يك عبارت را تاييد نكنهم اغلب آن را نمى يذيريم . & $\checkmark$ \\
\hline 4 & $\Delta$ & t & r & t & 1 & كشف اطلاعات جديد براى من يك تفريح و سرگرمى است . & $\wedge$ \\
\hline 4 & $\Delta$ & t & r & 4 & 1 & من براى اينكه بتوانم تصميم كيرى كنم زمانصرف مى كنهم & 9 \\
\hline \& & $\Delta$ & f & r & r & 1 & |تمايل دارم آنجه ديخران به من مى گويند فوراً بِيذيرم · & $1 \cdot$ \\
\hline 4 & $\Delta$ & f & r & t & 1 & |رفتار ديكَران مورد علاقه من نيست . & 11 \\
\hline \& & $\Delta$ & f & r & t & 1 & من به خود اطمينان خاطر دارم و دلخرم هستم . & $1 T$ \\
\hline 4 & $\Delta$ & i & $r$ & $r$ & 1 & بينهم يا موستانم به من من موم، فكر مى كندم كه من معمولاً در خصوص جيزهايى كه مى & 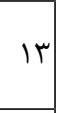 \\
\hline 4 & $\Delta$ & f & $r$ & r & 1 & من دوست دارم تا دلايل رفتار ديخران را بفهم . & 14 \\
\hline 4 & $\Delta$ & f & r & t & 1 & من معتقدم كه يادكيرى يك جيز مهيج است . & 10 \\
\hline 4 & $\Delta$ & f & r & $r$ & 1 & |معمولاً جيزهايى كه مي بينهم، مى خوانم يا مى شنوم را به همان صورتى & 19 \\
\hline 4 & $\Delta$ & i & r & $r$ & 1 & من به خودم احساس اطمينان ندارم . & IV \\
\hline
\end{tabular}


دو فصلنامه حسابدارى ارزشى و رفتارى، سال ينجم، شماره نهم، بهار و تابستان99"1

\begin{tabular}{|c|c|c|c|c|c|c|c|}
\hline 4 & $\Delta$ & f & r & $r$ & 1 & |خود جلب معلاً نا هماهنكى هاى احتمالى در توضيح مسائل، توجه من را به & $1 \wedge$ \\
\hline 4 & $\Delta$ & f & $r$ & $r$ & 1 & اغلب اوقات با تفكر افراد ديخر در گروه خود موافقم & 19 \\
\hline 4 & $\Delta$ & f & $r$ & $r$ & 1 & من دوست ندارم عجولانه تصميم گيرى كنم . & $r \cdot$ \\
\hline 9 & $\Delta$ & f & r & $r$ & 1 & من به خودم اعتقاد دارم و اعتماد به نفس دارم . & r) \\
\hline \& & $\Delta$ & f & | & $r$ & 1 & 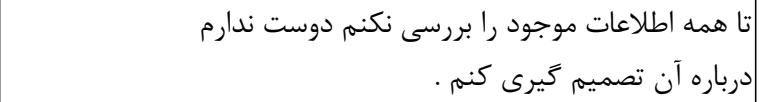 & $r t$ \\
\hline 4 & $\Delta$ & $f$ & r & $r$ & 1 & من تحقيق كردن براى يك دانش را دوست دارم . & $r r$ \\
\hline \& & $\Delta$ & f & r & $r$ & 1 & من اغلب درباره جيزهايى كه مى بينم و مى شنوم سئوال مى كنم. & TY \\
\hline 4 & $\Delta$ & f & r & $r$ & 1 & ديخران به راحتى مى توانند من را متقاعد كنند . & $r \omega$ \\
\hline \& & $\Delta$ & f & | & $r$ & 1 & كنند . منه ندرت توجه مى كنم كه جرا افراد به شيوه اى معين رفتار مى & rq \\
\hline \& & $\Delta$ & f & r & $r$ & 1 & | دوست دارم مطمئن شوم كه اكثر اطلاعات موجود را قبل از اتخاذ يك كرده ام . & $r V$ \\
\hline 4 & $\Delta$ & f & r & $r$ & 1 & |من از تلاش براى تعيين اينكه بدانم جيزى كه مى شنوم يا مى خوانم & $r \wedge$ \\
\hline 4 & $\Delta$ & f & r & $r$ & 1 & من از يادگيرى لذت مى برم . & rq \\
\hline 4 & $\Delta$ & f & r & $r$ & 1 & |كذابيت دارد كه ديكران انجام مى دهند دلايل انجام آن كار براى من & $r \cdot$ \\
\hline
\end{tabular}

\section{فهرست منابع}

آذين فر، كاوه؛ رويايى، رمضانعلى و يعقوب نزاد، احمد. (سوجا)، ارتباط بين ترديد حرفه اى و قضاوت حرفه اى حسابرسان مستقل، يزوهش هاى حسابدارى مالى و حسابرسى، شماره

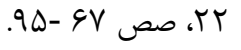

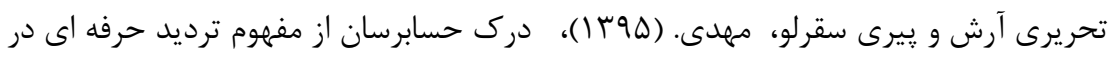

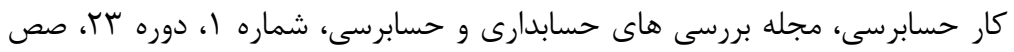

$$
.1 \% \Delta-11 V
$$

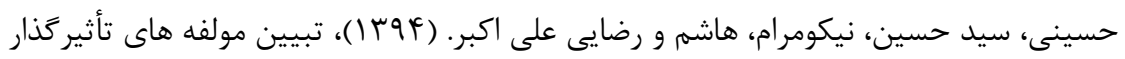

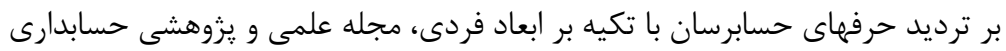

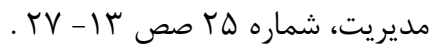

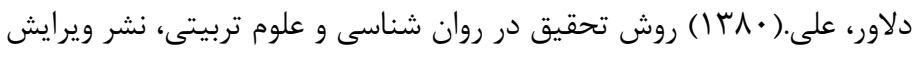


دكتر نيكومرام و همكاران، عواطف فردى و ترديد حرفه اى حسابرس

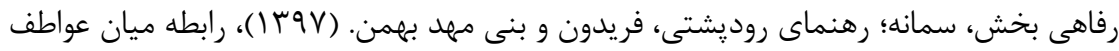

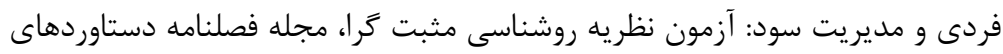

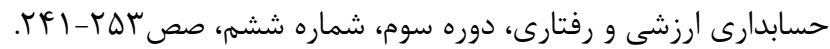

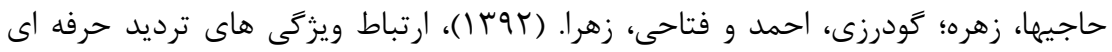

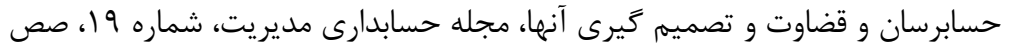

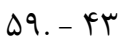

$$
\begin{aligned}
& \text { سعيدى گراغانى، مسلم و ناصرى، احمد. (991)، تاثير تيٍ شخصيتى بر قضاوت حرفه اى }
\end{aligned}
$$

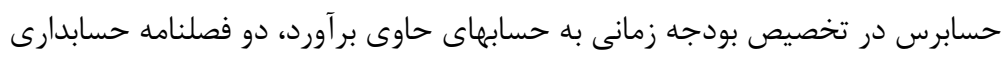

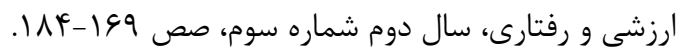

ACCA.2017. Banishing Bias? Audit Objectivity, and the Value of professional Scepticism. Available at: http://www.accaglobal.com/content/dam/ACCA_Global/Technical/ audit/pi-banishing-bias-prof-scepticism.pdf

Aschauer,E., M. Fink, A. Moro, K.Van Bakel-Auer, and B.WarmingRasmussen. 2017. Trust and Professional Skepticism in the Relationship between Auditors and Clients: Overcoming the Dichotomy Myth. Behavioral Research in Accounting.29(1):19-42.

Bagley, P. L. 2010. Negative affect: A consequence of multiple accountabilities in auditing. Auditing. Journal of Practice \& Theory 29 (2): 141-157.

Chiang,C.2016.Conceptualising the linkage between professional scepticism and auditor independence. Pacific Accounting Review, 28(2): $180-200$

Chung, J., J. R. Cohen, and G. S Monroe.2015. The Influence of a SelfInterest Threat to Auditor Independence and Emotion on Auditors' Inventory Valuation Judgments. Available at SSRN: https://ssrn.com/abstract $=2557630$

Cianci, A. M., and J. L. Bierstaker. 2009. The impact of positive and negative mood on the hypothesis generation and ethical judgments of auditors. Journal of Practice \& Theory 28 (2): 119-144.

Farag. M.S, and R.Z. Elias. 2016. The relationship between accounting students' personality, professional skepticism and anticipatory socialization, Accounting Education.25(2):124-138

Favere-Marchesi.A., and C.Emby.2017. The Alumni Effect \& Professional Skepticism: An Experimental Investigation. Accounting Horizons In-Press. https://doi.org/10.2308/acch-51920 
Forgas, J. P. 1995. Mood and judgment: The affect infusion model (AIM). Psychological Bulletin, 117(1): 39-66.

Forgas, J. P. and J. M. George .2001. Affective Influences on Judgments and Behavior in Organizations: An Information Processing Perspective, Organizational Behavior and Human Decision Processes 86(1): 3-34.

Franken, I. H. A., and P.Muris.2005. Individual differences in decisionmaking. Personality and Individual Differences, 39(1):991-998

Griffith, E. E., J. S.Hammersley, K.Kadous, and D.Young. 2015. Auditor mindsets and audits of complex estimates. Journal of Accounting Research, 53(1): 49-77.

Glover, S. M and D.F.Prawitt. 2014. Practitioner summary: Enhancing auditor professional skepticism: The professional skepticism continuum. Current Issues in Auditing, 8(2): 1-10.

Hammersley, J.S.2011.A review and model of auditor judgments in fraud-related planning tasks. Auditing: A Journal of Practice \& Theory. 30(4):101-128

Hurtt, R. K. 2010. Development of a Scale to Measure Professional Skepticism. Auditing: A Journal of Practice \& Theory 29(1): 149171

Isen, A.M., Shalker, T., Clark, M., \& Karp, L. (1978), "Affect, accessibility of material in memory and behavior: A cognitive loop? Journal of Personality and Social Psychology, 36, 1-12.

Koch.C, A.Köhler, and K.Yankova. 2016. Professional Skepticism and Auditor Judgment: Does Trait Skepticism mitigate the recency bias? Available at: https://papers.ssrn.com/sol3/papers.cfm?abstract_id=2880653

Kunda, Z. 2002. Social cognition: making sense of people. Cambridge, MA: MIT Press.

Lerner, J. S., and L. Z. Tiedens. 2006. Portrait of the angry decision maker: How appraisal tendencies shape anger's influence on cognition. Journal of Behavioral Decision Making, 19(2): 115-137.

Lindebaum, D.2013. Does emotional intelligence moderate the relationship between mental health and job performance? An exploratory study, European Management Journal31(3): 538-548

McKnight, C.A.,and W.F. Wright. 2011.Characteristics of relatively high-performance auditors. Auditing: A Journal of Practice \& Theory.30(2): 191-206.

Nelson, Mark W.2009. Model and Literature Review of Professional 


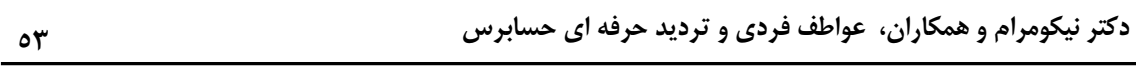

Skepticism in Auditing Auditing: A Journal of Practice \& Theory. 28(2): 1-34.

Peytcheva., M.2014. Professional skepticism and auditor cognitive performance in a hypothesis-testing task, Managerial Auditing Journal .291(1):.27-49.

Schwarz, N. 2004. Meta-cognitive experiences in consumer judgment and decision making. Journal of Consumer Psychology. 14(3):332348.

Thompson, M.M., M.E.Naccarato, K.C.H.Parker, and G.B. Moskowitz.2001. The personal need for structure and personal fear of invalidity measures: Historical perspectives, current applications, and future directions. In G. B. Moskowitz (Ed.), Cognitive social psychology: The Princeton symposium on the legacy and future of social cognition.12(3):19-39.

Watson, D., Clark, L. A., and A.Tellegen 1988. Development and validation of brief measures of positive and negative affect: The PANAS scales. Journal of Personality and Social Psychology. 54(6): 1063-1070.

Wegener, D. T., and R. E. Petty. 1994. Mood management across affective states: The hedonic contingency hypothesis. Journal of Personality and Social Psychology 66 (6): 1034-1048

Yan,H., and S.Xie. 2016. How does auditors' work stress affect audit quality?Empirical evidence from the Chinese stock market. China Journal of Accounting Research 9(4):305-319. 